\title{
Erratum to: Recommendations for the repair, the lining or the strengthening of concrete slabs or pavements with bonded cement-based material overlays Erratum pour: Recommandations pour la réparation, le re-surfaçage ou le renforcement des dallages industriels ou des chaussées en béton par un rechargement adhérent à base cimentaire
}

B. Bissonnette $\cdot$ L. Courard $\cdot$ H. Beushausen $\cdot$

D. Fowler · J. Silfwerbrand $\cdot$ M. Trevino •

A. Vaysburd

Published online: 22 November 2012

(C) RILEM 2012

1 Erratum to: Materials and Structures

DOI 10.1617/s11527-012-9929-8

Due to an unfortunate turn of events author Dr. Johan Silfwerbrand was mistakenly left out. This is most regretted by his fellow authors. Please find on this page the authors and their affiliations listed as they should be and this should be regarded by the reader as the final version.

The online version of the original article can be found under doi:10.1617/s11527-012-9929-8.

B. Bissonnette

Laval University, Quebec, QC, Canada

L. Courard ( $\square)$

University of Liège, Liege, Belgium

e-mail: Luc.Courard@ulg.ac.be

H. Beushausen

University of Cape Town, Cape Town, South Africa

D. Fowler - M. Trevino

The University of Texas at Austin, Austin, TX, USA

J. Silfwerbrand

The Royal Institute of Technology, Stockholm, Sweden

A. Vaysburd

Vaycon Consulting, Baltimore, MD, USA 